\title{
Molecular characterization of subcellular localization and nucleocytoplasmic shuttling of PRV UL54
}

\author{
Meili Li*, Shuai Wang, Junji Xing, Hong Guo, Chunfu Zheng \\ From Institut Pasteur International Network Annual Scientific Meeting \\ Hong Kong. 22-23 November 2010
}

Pseudorabies virus (PRV) UL54 protein localized almost exclusively to the nucleolus. By constructing a series of mutants, the putative nuclear localization signal (NLS), nucleolar localization signal (NoLS) and nuclear export signal (NES) of UL54 were for the first time mapped to amino acids ${ }^{45}$ RRRRGGRGGRAAR ${ }^{57},{ }^{61}$ RQRRR $^{65}$ and ${ }^{240}$ LQNLRLKLGPFL ${ }^{251}$, respectively. In addition, nuclear localization of UL54 was important for its transcriptional regulation of glycoprotein $\mathrm{C}$ promoter. The nuclear import of UL54 was abrogated by dominant negative RanGTP and importin $\beta 1$, respectively, indicating that UL54 targeted to the nucleus by means of a classic Ran- and importin $\beta$-dependent nuclear import mechanism. Heterokaryon assays demonstrated that UL54 was a nucleocytoplasmic shuttling protein and this property could not be blocked by leptomycin $B$, an inhibitor of the chromosome region maintenance 1 (CRM1). However, ectopic expression of the mRNA export receptor TAP(NXF1) promoted the nuclear export of UL54 and interacted with UL54, suggesting that UL54 shuttles between the nucleus and the cytoplasm via a TAP(NXF1), but not CRM1, dependent nuclear export pathway. The present study demonstrated that UL54 is a nucleolar protein, adding UL54 to the growing list of transactivators which localize to the nucleolus and shuttle between the nucleus and the cytoplasm.

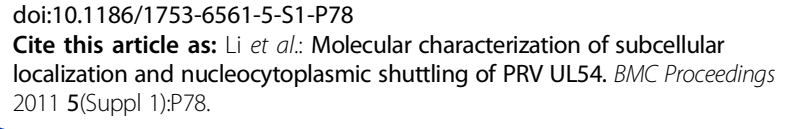

Wuhan Institute of Virology, Chinese Academy of Sciences, Wuchang, Wuhan 430071, PR China
Submit your next manuscript to BioMed Central and take full advantage of:

- Convenient online submission

- Thorough peer review

- No space constraints or color figure charges

- Immediate publication on acceptance

- Inclusion in PubMed, CAS, Scopus and Google Scholar

- Research which is freely available for redistribution
() Biomed Central 